\title{
Determinants of Profitability in Micro-enterprises Incorporated by Migrants in"Mercardo Artesanal”, Guayaquil-Ecuador
}

\author{
María Belén Bravo Avalos ${ }^{1}$, Maritza Lucía Vaca Cárdenas ${ }^{1}$ \& Gisella Nicole Miño Montero ${ }^{2}$ \\ ${ }^{1}$ Escuela Superior Politécnica de Chimborazo, Riobamba, Ecuador \\ ${ }^{2}$ Universidad Politécnica Salesiana, Guayaquil, Ecuador \\ Correspondence: Gisella Nicole Miño Montero, Gral Francisco Robles 107, Guayaquil, Ecuador. E-mail: \\ gminom1@est.ups.edu.ec
}

Received: July 22, 2020

Accepted: August 29, 2020

Online Published: September 5, 2020

doi:10.5430/rwe.v11n5p259

URL: https://doi.org/10.5430/rwe.v11n5p259

\begin{abstract}
The main objective of the study was to examine the effects on profitability of socioeconomic factors and business management skills of migrant micro-entrepreneurs. Our results are based on 162 surveys conducted with migrant businesspeople at Mercado Artesanal, in Guayaquil-Ecuador, between February 18-22, 2020. We applied a modified composite index developed in 2016 by Bell for evaluating entrepreneurial skills of Otavaleño migrants, who own micro-enterprises at Mercado Artesanal. We found that over $81 \%$ of the microfirms operated by migrants in the examined marketplace are profitable. Differences in profitability between migrant and resident micro-entrepreneurs are also discussed. Like prior study findings our results suggest that migrant micro-entrepreneurs show greater business performance compared to local businessmen. In addition, a straightforward profitability index, SPI, was calculated for assessing the determinants of profitability of local and migrant micro-entrepreneurs. Authors believe that the proposed index should be useful mainly for micro-enterprises and market sellers, where the customary measurement methods cannot be applied.
\end{abstract}

Keywords: entrepreneurs, socio-economy, discriminant analysis, management skills, migrants and residents

\section{Introduction}

Over the past decades the effects of migration on global and local economy have been central to development and business-related studies (Murphy, 1999). Although continuously increasing scholar attention is paid to migration flows in European countries (Barnes and Cox, 2007; Vershinia et al., 2007), studies that examine relations between business profitability and domestic migration in Latin American countries are available only in modest numbers. This is unfortunate, when considering that the micro-business sector provides income for millions of people in Latin American and Caribbean countries (Bárcena, 2019). Researchers in Mexico found links between migration and the "health" of a country's small business sector (Díaz-Briquest and Weintraub, 2019). Moreover, literature indicates that ethnic diversity improves organizational performance (Becker, 1957; Cox, 1993; Richard, 2000; Richard et al., 2003; Richard et al., 2004; Herring, 2009; Ely et al., 2012). Therefore, studies that analyze the skills and socioeconomic factors of migrant micro-entrepreneurs contribute to the better understanding of changes in local economy.

In their study published in 2020 Kone and coworkers (Kone et al., 2020) examined links between self-employment and reasons of migration. Authors also addressed the question, whether migrants are more entrepreneurial as compared to local people. It was found that at the beginnings, migrated people are more engaged in self-employment than residents.

Our current study was inspired by a complex exploratory analysis carried out by Worku in 2019. The author reported a significant correlation between level of entrepreneurial skills, the ability to raise business loans, and profitability in micro-businesses operated by migrant women. Inspired by Kone and colleagues' findings, we felt it important to expand the survey designed by Worku toward exploring the causes of migration, and differences in profitability between migrant and resident micro-entrepreneurship. In addition, we present a self-designed simplified profitability index.

\section{Materials and Methods}

Research was conducted between February 18-22, 2020. A total of 30 questions were addressed with the purpose of 
realizing an exploratory cross-sectional designed survey, according to Worku 2019. Survey questions were divided into three groups and distributed to 162 migrants $(n=162)$ :

1. general characteristics of migrant micro-entrepreneurs $(n=162)$,

2. profitability of businesses $(n=162)$, and

3. experienced difficulties $(\mathrm{n}=162)$.

We applied the composite index designed by Bell (2016) for evaluating entrepreneurial skills of Otavaleño migrants (coming from canton Otavalo, Province of Imbabura, Ecuador), who own micro-enterprises at Mercado Artesanal Guayaquil 20 de Julio (Mercado Artesanal), Guayaquil, Guayas province- Ecuador. To analyze marketing skills, we used a composite index according to Wedel and Kannan (2016). Discriminant analysis was done according to Tibshirani et al. (Tibshirani et al., 2015) and ordered logit analysis developed by Faraway (2016) was applied to determine influential predictors of profitability in businesses.

Amendments of the study: Considering that prior studies were performed to examine local-economy related factors, to better understand the examined market, here we have made the following amendments in the questionnaire: (a) perception about the level of support from members of the local community; (b) cultural troubles between local registered members; and (c) previous experience in the application of loans from usurers. We added a new factor into the analysis: (d) loosening rate of foreign customers due to the lack of (English) language skills. This criterion was motivated by the significant presence of foreign customers (mainly U.S. tourists) in the examined marketplace.

Also, we compared profitability between migrant and resident micro-entrepreneurs. Human participant data: 162 migrants (representing $86 \%$ of the total number of registered micro-entrepreneurs), and 30 resident micro-entrepreneurs were selected from Mercado Artesanal. To examine differences in profitability between migrant and resident micro-entrepreneurships, 30 migrant surveys were randomly selected from 162. Simplified profitability index (SPI) was calculated by dividing the number of profitable businesses by the total number of businesses within the same group, as described in Equation 1:

$$
S P I=\frac{N P B}{N T B} * 100
$$

Where,

NPB is Number of Profitable Businesses within the group in focus, and

NTB is Number of Total Businesses within the group in focus.

Statistical analysis was performed with SPSS (version 22.0).

Ethical statement: The Committee of Mercado Artesanal Guayaquil 20 de Julio, Guayaquil approved this study. Participants provided informed oral consent to participate in the study prior to its start. Oral consent was obtained from participants instead of written consent because of time constraints and illiteracy of some participants. Surveys were filled on the spot on self-assessment basis, anonymized.

\section{Results and Discussion}

From survey results one can state that almost $70 \%$ of migrant entrepreneurs came to Guayaquil from other provinces, seeking more favorable socioeconomic conditions. All rented their local business place at the Mercado Artesanal. Over $65 \%$ of the sellers are running their business for 8 years or longer. Almost $60 \%$ of them earned a low educational level (grade 12 or less) (Table 1). About $45 \%$ of sellers are married. Table 2 reveals that over $80 \%$ of micro-enterprises are profitable. All sellers in Mercado Artesanal can rent local business places exclusively, when the market is owned by the municipality. Nearly $55 \%$ of the surveyed sellers have adequate business skills determined by Dell's standards (Dell, 2016). Less than $15 \%$ of the entrepreneurs possess excellent marketing skills, as determined by the standards developed by Wedel and Kannan (2016); and only 8\% of surveyed sellers have appropriate level of networking skills, expressed by Bone's standards (2017). Surprisingly, over $80 \%$ of surveyed micro-entrepreneurs are capable of ordering products in bulk, on credit, from wholesale suppliers (Table 2) 


\begin{tabular}{|c|c|}
\hline Variable of study & $\begin{array}{l}\text { Number of respondents and } \\
\text { percentage }\end{array}$ \\
\hline \multirow{3}{*}{$\begin{array}{l}\text { Motivation of } \\
\text { migration }\end{array}$} & $\begin{array}{l}\text { Better socioeconomic values (more } \\
\text { profitable) } 112 ; 69.14 \%\end{array}$ \\
\hline & Safety and security $29 ; 17.90 \%$ \\
\hline & $\begin{array}{l}\text { Better infrastructure (of the } \\
\text { marketplace) } 21 ; 12.96 \%\end{array}$ \\
\hline \multirow{2}{*}{$\begin{array}{l}\text { Ownership of the } \\
\text { place }\end{array}$} & Own None; $0 \%$ \\
\hline & Rent $162 ; 100 \%$ \\
\hline \multirow{3}{*}{ Operation time } & Three years or less None; $0 \%$ \\
\hline & From 4 to 6 years $56 ; 34.57 \%$ \\
\hline & 8 or more years $106 ; 65.43 \%$ \\
\hline \multirow{4}{*}{ Education level } & Illiterate $10 ; 6.2 \%$ \\
\hline & Primary school $47 ; 29.01 \%$ \\
\hline & Secondary school 97; 59.87\% \\
\hline & College/University $8 ; 4.93 \%$ \\
\hline \multirow{3}{*}{ Age } & 20 years old or less None; $0 \%$ \\
\hline & Between $21-40$ years $111 ; 68.52 \%$ \\
\hline & 41 or more $51 ; 31.48 \%$ \\
\hline \multirow{5}{*}{ Marriage status } & Single $17 ; 10.49 \%$ \\
\hline & Married $73 ; 45.06 \%$ \\
\hline & Divorced $25 ; 15.43 \%$ \\
\hline & Dowager $9 ; 5.56 \%$ \\
\hline & Companion $38 ; 23.46 \%$ \\
\hline
\end{tabular}

Our results evidenced that none of the sellers apply a business plan to organize and operate their activities. Almost $30 \%$ of participants used their own savings as the initial capital (Table 3). Around $20 \%$ benefit of family support, and only $8 \%$ of the initial capital comes from bank loans. All local sellers acquired previous experience in applying loans from usurers. $40 \%$ of surveyed micro-entrepreneurs are experienced with bank loans, and nearby $70 \%$ of them have applied at least once for loans from micro-finance agencies. $13 \%$ of sellers are experiencing customer debts. None of the respondents declared difficulties in opening a bank account. Although violence was not reported lately, cultural problems are present; according to our survey results, $43 \%$ of surveyed micro-entrepreneurs experienced cultural problems, mainly between locals (people form Guayas province) and migrants (people mostly form Highland, such as Otavalo). Neither security issues, nor violence or theft in the market was reported. 10\% of sellers experienced rental problems (over 3 months debt per year). No trade license problems were disclosed. Discriminant analysis did not evidence any significant correlation between migration and social capital participation for fund raising. Logit analysis showed high Odds Ratio (4.34) in Ability to order products in bulk on credit as compared to Worku, Z. (2019). Figure 1 reveals the standardized mean scores of profitability predictors in all examined businesses $(\mathrm{n}=162)$, grouped into three categories: profitable; not profitable, and all businesses (Figure 1). 


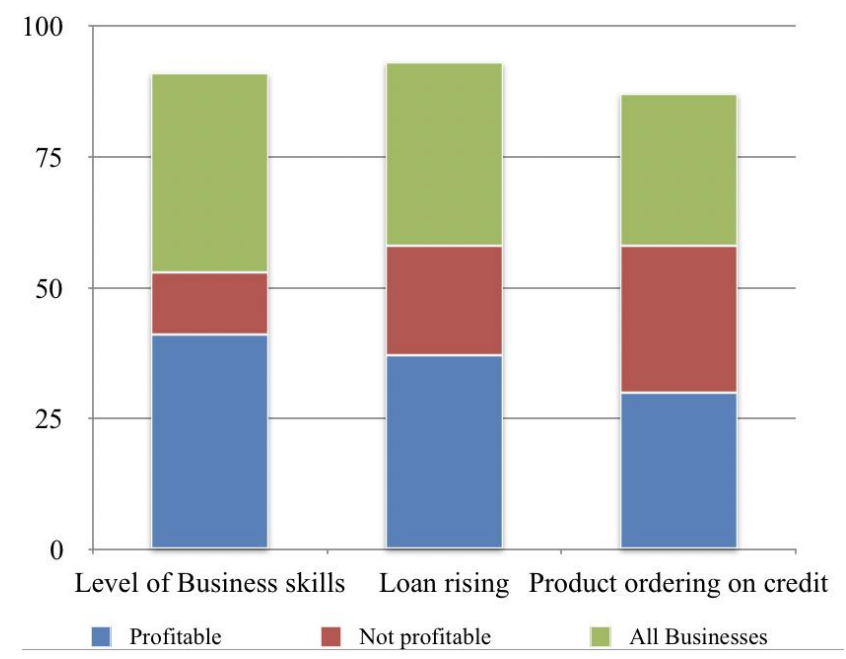

Figure 1. Standardized mean scores of profitability predictors $(n=162)$

Table 2. Profitability assessment of entrepreneurs $(n=162)$

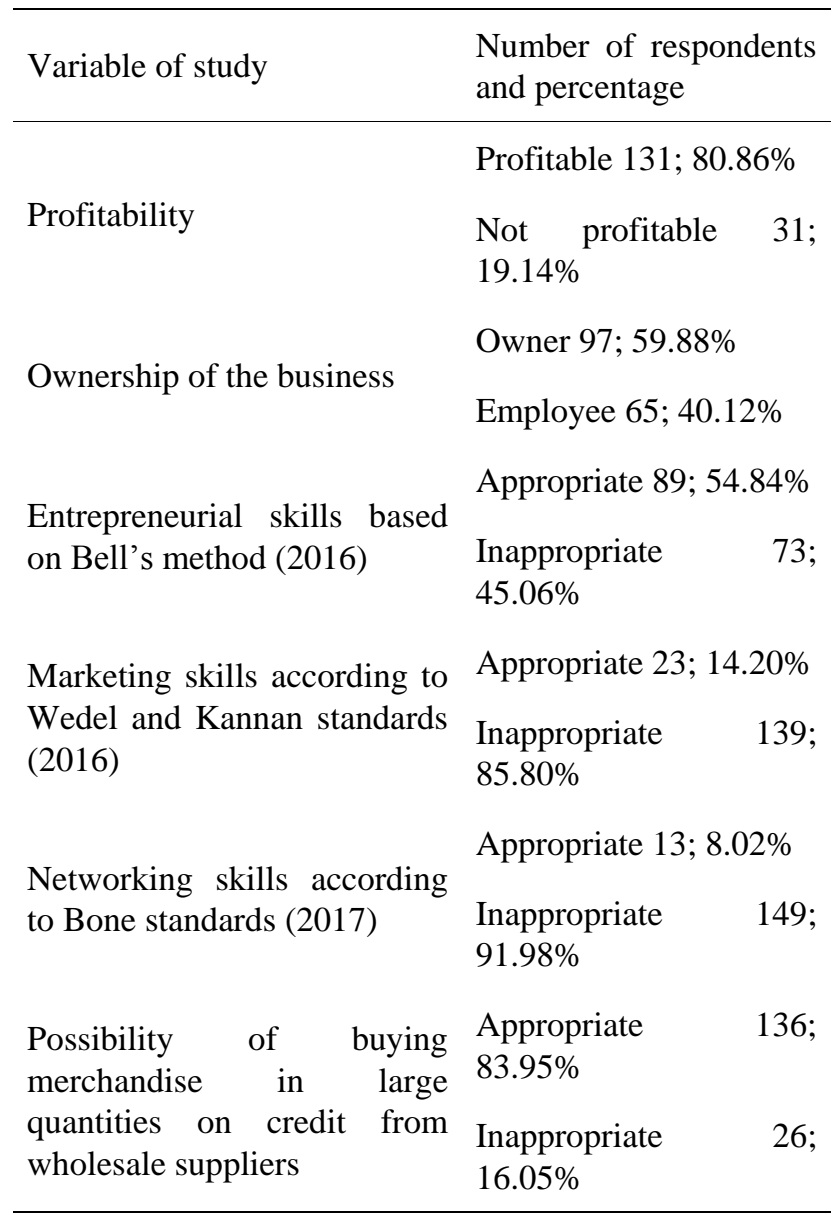


Table 3. Business operation and difficulties experienced $(n=162)$

\begin{tabular}{|c|c|}
\hline Variable of study & Number of respondents and percentage \\
\hline \multirow{2}{*}{ There is a business plan (seen by the data collector) } & Yes \\
\hline & No $162 ; 100 \%$ \\
\hline \multirow{2}{*}{ Product inventory (viewed by data collector) } & Yes $33 ; 20.37 \%$ \\
\hline & No $129 ; 79.63 \%$ \\
\hline \multirow{5}{*}{ Initial capital source } & Own savings $48 ; 29.63 \%$ \\
\hline & Family savings $34 ; 20.99 \%$ \\
\hline & Social capital $26 ; 16.05 \%$ \\
\hline & Bank Loan $13 ; 8.02 \%$ \\
\hline & Donation None; $0 \%$ \\
\hline \multirow{2}{*}{ Previous experience in bank loans } & Yes $65 ; 40.12 \%$ \\
\hline & No $97 ; 59.88$ \\
\hline $\begin{array}{l}\text { Previous experience in applying for loans from microfinance } \\
\text { agencies }\end{array}$ & Yes $112 ; 69.14$ \\
\hline \multirow{2}{*}{ Customer debt } & Yes $21 ; 12.96$ \\
\hline & $141 ; 87.03 \%$ \\
\hline \multirow{2}{*}{ Difficulty opening a bank account } & Yes None; $0 \%$ \\
\hline & No $162 ; 100 \%$ \\
\hline \multirow{2}{*}{ Rental problems } & Yes $17 ; 10.49 \%$ \\
\hline & No $145 ; 89.51$ \\
\hline Storage for merchandise & Yes $167 ; 100 \%$ \\
\hline \multirow{3}{*}{ Theft of Merchandise } & No None; $0 \%$ \\
\hline & Yes None; $0 \%$ \\
\hline & No $162 ; 100 \%$ \\
\hline \multirow{2}{*}{ Cultural problems } & Yes $70 ; 43.21 \%$ \\
\hline & No $92 ; 56.79 \%$ \\
\hline \multirow{2}{*}{ Transportation problems } & Yes None; $0 \%$ \\
\hline & No $162 ; 100 \%$ \\
\hline \multirow{2}{*}{ Violent attacks by burglars } & Yes None; $0 \%$ \\
\hline & No $162 ; 100 \%$ \\
\hline Security issues & Yes None; $0 \%$ \\
\hline \multirow{2}{*}{$\begin{array}{l}\text { Perception of the level of support from members of the local } \\
\text { community }\end{array}$} & Yes $71 ; 43.83 \%$ \\
\hline & No $91 ; 56.17 \%$ \\
\hline
\end{tabular}


Finally, we observed $20 \%$ greater SPI values in micro-enterprises managed by migrants compared to locals, reflected in the ratio of number of profitable businesses within the group, and total number of businesses within the group, as shown on Figure 2.

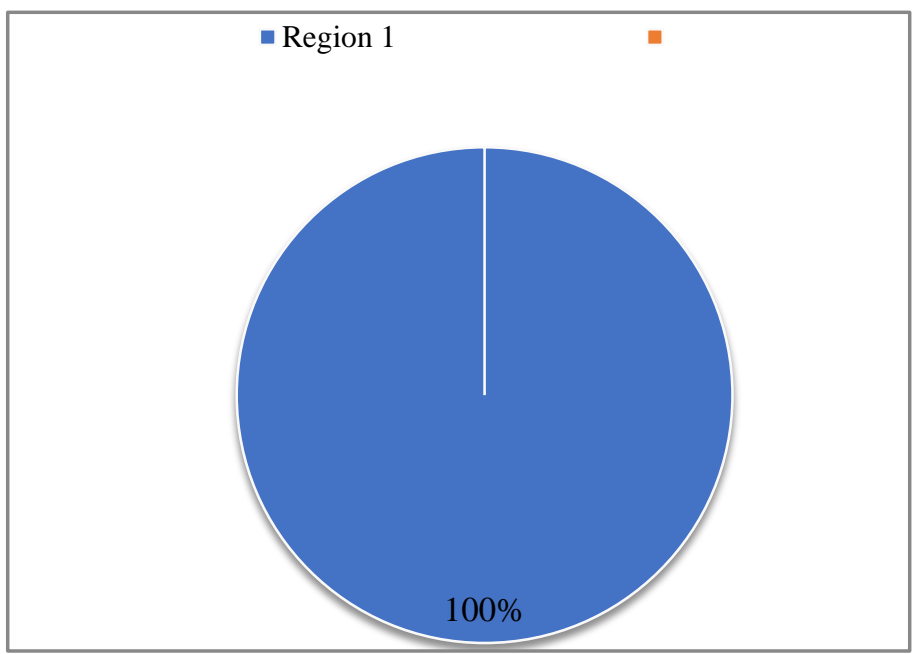

Figure 2. Difference in SPI index between migrant and local entrepreneurs

SPImigrant value was 81 in migrant group, while SPIlocal 54 value can be observed in the group of local entrepreneurs.

The majority (over 95\%) of sellers, both migrant and local micro-entrepreneurs loose foreign (mainly U.S. tourists) customers because of the lack of English language skills.

\section{Conclusions}

Like prior study findings (Worku, 2019) our results suggest that migrant micro-entrepreneurs show greater business performance compared to local businessmen's achievements. Considering that Ecuador is among the main fruit (e.g., banana) (Melendez et al., 2020) and rose producers and exporters worldwide (Hernández et al., 2010), and the complete economic shutdown of the country, particularly Guayaquil is experiencing hardship caused by quarantine and traffic regulations (DRC, 2020), one can state that there is a great demand for analyzing determinants of profitability of local micro-entrepreneurs operated by migrants. This will enable them to be prepared for the economic recovery after quarantine.

In addition, a straightforward profitability index SPI was calculated for assessing determinants of profitability of local and migrant micro-entrepreneurs. Authors envisage that the proposed index should be useful primarily for micro-enterprises and sellers in markets, where the customary measurement methods cannot be applied. Furthermore, considering the high failure rate in selling to foreign customers and the location of the investigated marketplace (near the main touristic attractions in the city), authors recommend to micro-entrepreneurs to improve their language skills and/or hire fluent English speaking sellers in the marketplace.

\section{References}

Bárcena, A. (2019). Drivers of development and transformation: A Latin American and Caribbean perspective. International Journal of Labour Research, 9(1), 173-193.

Barnes, I., \& Cox, V. (2007). EU migrants as entrepreneurs in Lincolnshire: exploiting the enterprise culture. Entrepreneurship and Innovation, 8(3), 209-18.

Becker, G. S. (1957). The economics of discrimination. Chicago: University of Chicago Press.

Bell, R. (2016). Unpacking the Link between Entrepreneurialism and Employability: An assessment of the relationship between entrepreneurial attitudes and likelihood of graduate employment in a professional field. Education+Training, 58(1), 2-17.

Cox, T. (1993). Cultural diversity in organizations: theory, research, and practice. San Francisco: Berrett Koehler. 
Díaz-Briquests, S., \& Weintraub, S. (2019). Migration, Remittances, and Small Business Development (4th ed.). Sidney: Routledge.

DRC (Dama Research Center limited). (2020). Effect of transport measures and curfew against COVID-19 spread on air pollution (TSP) in Ecuador's three most populous cities. DRC Sustainable Future 2020, 1(1), 54-59. https://doi.org/10.37281/DRCSF/1.1.7

Ely, R. J., Padavic, I., \& Thomas, D. A. (2012). Racial diversity, racial asymmetries, and team learning environment: effects on performance. Organization Studies, 33(3), 341-362. https://doi.org/10.1177/0170840611435597

Hernández, I., Nathalie, C., et al.. (2010). The Discovery of New Export Products in Ecuador (June 2010). IDB Working Paper No. 47.

Herring, C. (2009). Does diversity pay? Race, gender, and the business case for diversity. American Sociological Review, 74(2), 208-224.

Kone, Z., Ruiz, I., \& Vargas-Silva, C. (2020). Self-employment and reason for migration: are those who migrate for asylum different from other migrants?. Small Bus Econ (in press). https://doi.org/10.1007/s11187-019-00311-0

Melendez, J. R., Peñalver, A., Pincay, P. F., Pulgar, N. L., \& Cayo, M. (2020). Determination of factors involved in the rejection of bananas (Musa acuminata) intended for international commercialization. DRC Sustainable Future, 1(1), 48-53. https://doi.org/10.37281/DRCSF/1.1.6

Murphy, R. (1999) Return migrant entrepreneurs and economic diversification in two counties in south Jiangxi, China. Journal of International Development, 11(4), 661-672.

Richard, O. C. (2000). Racial diversity, business strategy, and firm performance: a resource-based view. Academy of Management Journal, 43(2), 164-177. https://doi.org/10.5465/1556374.

Richard, O. C., Barnett, T., Dwyer, S., \& Chadwick, K. (2004). Cultural diversity in management, firm performance, and the moderating role of entrepreneurial orientation dimensions. Academy of Management Journal, 47(2), 255-266. https://doi.org/10.5465/20159576

Richard, O., McMillan, A., Chadwick, K., \& Dwyer, S. (2003). Employing an innovation strategy in racially diverse workforces: effects on firm performance. Group \& Organization Management, 28(1), 107-126. https://doi.org/10.1177/1059601102250022

Tibshirani, R., Wainwright, M., \& Hastie, T. (2015). Statistical learning with Sparsity: The lasso and generalizations. London: Chapman and Hall/CRC.

Vershinina, N., Barrett, R., \& Meyer, M. (2011). Forms of capital, intra-ethnic variation and Polish entrepreneurs. Work, Employment and Society, 25(1), 101-17.

Wedel, M., \& Kannan, P. K. (2019). Marketing analytics for data-rich environments. Journal of Marketing (AMA/MSI Special Issue), 80, 97-121.

Worku, Z. (2019). Determinants of profitability in small enterprises operated by migrant women. Academy of Entrepreneurship Journal, 25(4). Retrieved from https://www.abacademies.org/articles/determinants-of-profitability-in-small-enterprises-operated-by-migrant-w omen-8863.html

\section{Copyrights}

Copyright for this article is retained by the author(s), with first publication rights granted to the journal.

This is an open-access article distributed under the terms and conditions of the Creative Commons Attribution license (http://creativecommons.org/licenses/by/4.0/). 